\title{
Darko Radinja*
}

IZVLEČEK

UDK 911.2:378.096(1919-1989)

Prispevek obravnava razvoj fiziðne geografije na ljubljanski univerzi. Deli ga na štiri obdobja po vodilnih strokovnjakih.

ABSTRACT

UDC 911.2:378.096(1919-1989)

SEVENTY YEARS OF PHYSICAL GEOGRAPHY AT THE UNIVERSITY OF LJUBLJANA

The article discusses four different periods within the development process of physical geography at the University of Ljubljana.

V sedmih desetlet jih filozofske fakultete je podobno kot celotna geografija tudi fizi¿na (naravna) doživela marsikatero razvojno spremembo, ki ni bila le formalne, organizacijske narave, temvę tudi vsebinske. Njen položaj se je zato $\mathrm{v}$ marsiðem spreminjal znotraj geografije pa tudi navzven. Posebno zadnja tri desetletja so bila v tem pogledu izredno dinamiexna.

Sedemdeset let za univerzo sicer ni posebno veliko, vex̌ pa pomeni za stroko, kakršna je geografija, se posebej, ko mislimo na pokrajino kot njen osrednji predmet. Ta se je, č se omejimo na slovensko pokrajino, v nekaj desetletjih, takorekoč $v$ dobi ene generacije, spremenila bolj, kakor prej v stoletjih. Podobno se je v tem casu predrugačila družba (njena struktura in organizacija) in njen odnos do narave. Ta se nikoli ni bil tako perex, kakor je danes. Za našo pokrajino velja to morda se bolj, kakor za katero drugo, s tem pa tudi za geografijo kot nacionalno vedo, saj se je funkcioniranje družbe, ki je cedalje bolj dinamiæni preoblikovalec pokrajine, v tem casu mocno stopn jevalo.

Sedemdesetletnica ni posebno zaokrožena doba (kakor npr. 50-letnica, 75-letnica ali 100-letnica), vseeno pa tudi dekadne obletnice nudijo priložnost, da se jih spomnimo, vsaj bežno pregledamo opravljeno pot, se ob tem zamislimo in se zazremo tudi naprej. Doslej so bile zabeležene tri obletnice univerze, 10-letnica (1929. leta), 30-letnica (1949. leta) in 50-letnica (1969. leta), in ob njih naletimo na nekatere, takrat zapisanc geografske misli. Ni pa bila zabeležana 25 -letnica, ki je padla v tragixna okupacijska leta (1944. leta).

* Dr., univ.prof., Oddelek za geografijo, Filozofska fakulteta, 61000 Ljubljana, Aškerčeva 12 , YU. 
Žal se pri vpogledu $v$ dosedanji razvoj ne moremo nasloniti na arhivsko gradivo, ki bi bilo zbrano na enem mestu in ustrezno urejeno. Ker poleg tega na tem mestu tudi ni dovolj Casa na voljo, gre v priložnostnem prispevku bolj za osebne poglede, kakor za kaj drugega. To velja zlasti za pregled povojnega razvoja, kjer se zaradi osebne izkuSnje vpleta vanj tudi vpogled prizadetega udeleženca, in ne le neprizadetega opazovalca. In ko skušmo osvetliti razvoj fizicne geografije, se ni mogoðe vselej omejiti samo nanjo. V̌asih jo je lažje razumeti v luci celotne geografije.

Delitev na fiziðno in družbeno geografijo je tradicionalna, tako tudi na ljubljanski univerzi, ki jo je spremljala od njenega zacetka dalje, toda $v$ drugaxnem pomenu pred vojno kakor po njej. Tako sta bili se ob ustanovitvi za geografijo predvideni dve stolici. Oglejmo si najprej, kako se je spreminjal položaj geografije v organizacijskem pogledu in v tem okviru tudi fiziæne.

Če smo natančni, geografija na ljubljanski univerzi pravzaprav letos ne praznuje sedemdesctletnice, manjka ji vsaj leto, ce že ne dve. Zaživela je namreð 1920. leta, ko je bil nastavljen prvi profesor geografije, in sicer fiziðni geograf iz Hrvatske dr. A.Gavazzi, ki pa je z delom zacel leto kasneje (1921.). Znaxilnejse pa je to, da so tedanji geografski inštitut ustanovili (1921) v okviru filozofske fakultete, ki pa je bila drugažna od sedanje, saj je poleg humanistiennih obsegala tudi naravoslovne vede. S tega vidika je bistvu gcografije tedanji organizacijski položaj ustrezal. Tako je ostalo tudi vseh prvih trideset let, vse do 1949. leta. Takrat so se iz filozofske fakultete izlo$\chi_{i l e}$ nehumanistixne vede $z$ geografijo vred ter se organizirale v novo, prirodoslovno-matematǐno fakulteto. Žc cez nekaj lct (1955) sta se fakulteti ponovno združili, tokrat y prirodoslovno-matematixno-filozofsko fakulteto (PMF), a se cez dobro leto (1957) znova lozili, vendar je geografija ふe naprej ostala na naravoslovni fakulteti. Šcle od leta 1961 dalje, kmalu bo že 30 let, je geografija znova v okviru filozofske fakultete, ki pa je zožena na humanistǐne vede, kar za geografijo ni brez pomena. Saj ji ta položaj že zaradi njeneģa povezovanja $z$ naravoslovjem in družboslovjem hkrati, veliko manj ustreza, vsckakor manj kakor v prvi polovici njenega obstoja. Med drugim so na sedanji fakulteti gcografske povczave $\mathrm{z}$ naravoslovnimi vedami otežkoðene, kar pa ne prizadeva le fizið̌ne geografije, temveð̌ celotno.*

Organizacijski položaj geografije, kakrð̌n je zadnja tri desetletja na ljubljanski univerzi, je v državi edinstven. Edino v L jubljani je geografija v okviru filozofske fakul-

* Takratna reorganizacija je sledila aplikativnemu principu: temeljne vede naj bi se tudi organizacijsko povezova!e $\mathrm{z}$ aplikativnimi, npr. biologija $\mathrm{z}$ agronomijo (na BTF). Geografija je imela v načelu tri možnosti: upoštevaje njeno pedagoško aplikacijo ostati bodisi na naravoslovni fakulteti ali preiti na filozofsko, upoštevaje njeno nepedagoško aplikacijo pa preiti na ustrezno tehnično fakultcto in se pridružiti npr. prostorsko-planerski aplikaciji (FAGG). Geografija se je odloxila za naravoslovno fakulteto, potisnjena pa je bila na humanistið̌no (filozofsko). 
tete, povsod drugod je na prirodoslovnih fakultetah, ce izvzamemo skopsko univerzo, ki je do nedavna imela po moskovskem vzgledu svojo, geografsko fakulteto. V lastno fakulteto se je pravkar organizirala tudi geografija na beograjski univerzi, ki je bila doslej ves cas na prirodoslovni fakulteti. Tudi drugod po svetu za geografijo ni znacilno, da bi jo na univerzah gojili v okviru humanistike. Toda na ljubljanski filozofski fakulteti je geografija omenjeni položaj le napol izkoristila, se najveđ $v$ družboslovnem pomenu, manj pa v humanistixnem.

Organizacijski položaj geografije je potemtakem v povojni dobi manj ustrezen, kakor pred njo. Ni pa nakljucno, da je $v$ drugi polovici petdesetih let geografija prešla najprej v okvir naravoslovne fakultete, po letu 1960 pa v okvir družboslovne oziroma filozofske. K temu niso pripomogle ie zunanje okolišine (povojni sistem neprestanega spreminjanja), temveð tudi notranje, seveda kot odziv zunanjih, tako tudi spremenjeno razmerje med fiziěno in družbeno geografijo. $Z$ naglim tehnoloskkim in industrijskim razvojem zahodnega sveta po drugi svetovni vojni se je namrę zacelo uveljavljati naziranje, da je razvoj sodobne družbe bolj odvisen od njenih notranjih silnic kakor od naravnih. Tako so tudi $v$ delu geografije zaceli naravo vrednotiti bolj kot pridobitno sredstvo, kakor kaj drugega. Med geografi je tako narascalo zanimanje za družbenogeografsko probiematiko, in vzporedno s tem se je večal tudi delež vanjo usmerjenih geografov. Od tu so se sirile tudi težnje po zožcvanju fizicne geografije na valorizacijo naravnih razmer. Šele $v$ zadnjem desetletju cedalje bolj pereča problematika degradacije okolja in njegovega varstva vse bolj opozarja na zmotnost oziroma enostranost omenjenih naziranj.

Če je položaj fizix̌ne geografije znotraj stroke njena stvar, je celotni položaj stroke v okviru univerze vendarle sirši. Neustreznost njenega sedanjega organizacijskega položaja bi bilo treba kljub togi organizacijski strukturi univerze ublažiti vsaj z večjo samostojnostjo geografije znotraj fakultete, predvsem pa z vecjim posluhom za njene specificne potrebe.* S tega vidika so za geografijo na sedanji filozofski fakulteti pereč zlasti študijske in raziskovalne oblike, ki za humanistične vede niso tako znacilne (laboratorijsko delo; terensko delo, povezano $\mathrm{z}$ instrumentalno opremo; kartografska oprema in kartografsko delo pa tudi druge posebnosti, povezane z usposabljanjem studentov za nepedagoßka aplikacije geografije, ki terjajo tehniki bližje nacine dela itd.). Seveda pa omenjeni vidiki niso edini. Položaj geografije v okviru filozofske fakultete geografi doslej pravzaprav nismo do kraja premislili. Kakšne so npr. njene možnosti, ๔e jih ne obravnavamo le s socioloskega, temvec tudi filozofskega, prostorskega ali celo behavioristiłnega vidika?

* Poučna je nova organizacija geografije na beograjski univerzi, ki je sicer ostala v okviru prirodoslovne fakultete, vendar znotraj nje organizirana $v$ lasini, geografski fakulteti. 
Ko je bil ob znanih organizacijskih in drugih spremembah, ki so univerzo pretresle na pragu sestdesetih let, dotedanji geografski institut FF poimenovan $v$ oddelek (in kasneje $v$ pedagoško-znanstveno enoto ter nato ponovno $v$ oddelek), je ta kmalu zatem preko Geografskega drustva Slovenije uveljavil ustanovitev novega geografskega instituta (1961), vendar ne oddelenega ali fakultetnega, temvex neposredno pri univerzi. Do njega je prišlo prav z namenom, da omogoxi organizirano geografsko raziskovalno delo na enem mestu, predvsem pa enotno zasnovano ter utemeljeno ne glede, kje na univerzi, fakulteti ali vißji soli so geografi zaposleni, v prvi vrsti seveda geografom $z$ matixnega oddelka. Ta zasnova se je dve desetletji vsaj deloma uresnicevala, vendar je bila kasneje prekinjena zaradi zunanjih, nestrokovnih razlogov, predvsem zaradi principov samoupravljanja. Geografski institut pri univerzi se je tako sicer osamosvojil, obvisel pa je v zraku. Od prvotne zasnove je obdržal pravzaprav lc ime, sicer z univerzo nima niðesar ve` skupnega. Tako je prislo do situacije, ko je matixna geografija ostala brez lastne znanstvene organizacije. V primerjavi s prejšnjo se je položaj poslabక̌al, ceprav že prej ni bil idealen, ker je generiral dualizem geografije. Fizični geografi so se namrex vkljucevali v raziskovalno delo geografskega instituta akademije, drugi pa geografskega inštituta univerze, ki pa ga je oddelek vendarle usmerjal. Dualistixna orientacija gcografije se je takrat poglabljala tudi zaradi tovrstne organizacijske osnove, ki se je med drugim utemeljevala $\mathrm{z}$ delitvijo dela. S kasnejšo, že omenjeno samoupravno osamosvojitvijo geografskega inštituta univerze (podobna reorganizacija je zajela tudi znanstveno delo na akademiji) se je matixna geografska ustanova na filozofski fakulteti morala, kljub dvema geografskima inštitutoma, vkljuxiti v tretjega, negeografskega, namrex v splosni znanstveni institut na faulteti. Povezava $\mathrm{z}$ geografskima institutoma je $\mathrm{s} t \mathrm{~cm}$ bistveno oslabela, kolikor ni spioh zamrla. To ni bilo v prid nobeni od tch ustanov pa tudi ne geografiji kot celoti. Ta absurd je bil le konkretizacija mnogo siršega, izvirajočega iz splošne organizacije znanstvenega dela in organizacije družbe nasploh. Na raziskovalno delo vse to ni vplivalo spodbudno, morda še najmanj na geografski oddelck FF, kjer so se organizacijskin zagatam raziskovalnega dela pridružile కe vprasłijive కtudijske reforme in posiedicc usmerjenega izobraževanja sploh. Stalne spremembe v zadnjih dveh, treh desctlet jih so namrec, cc drugega ne, preko potrebe vznemirjale raziskovalno in pedagoško delo ter onemogocale ustaljenost, ki je za tovrstno delo se kako potrebna.

Razvoj geografije na univerzi lahko razdelimo na vec obdobij. Prvih sedem let (1920-1927) moremo oznaciti kot Gavazzijevo obdobje, ko so bili postavljeni organizacijski in c̈rugi temelji: poleg stolice (1920) je bilo rcalizirano se asistentsko mesto (1922), ki ga je zasedel dr. V.Bohinec, pridobljeni so bili prvi prostori, ustanovljen je bil geografski inštitut (1921), ki je deloval do 1960 . lcta, torej polnih 40 let; ustanovljeni sta bili nadalje geografska knjižnica in kartografska zbirka. Gavazzi je razsiril tudi meteorolosko mrežo $v$ Sloveniji, reorganiziral je Zavod za metcorologijo in geodinamiko. Predusem pa velja omeniti, da je bil Gavazzi fizixni geograf, pravza- 
prav hidrogeograf, saj je s tega področja na dunajski univerzi tudi doktoriral. Zato ni nakljuxje, da segajo na ljubljanski univerzi zacetki fiziŁnogeografskega, pravzaprav hidrogeografskega laboratorija prav v ta cas.*

Ko govorimo o prvem obdobju, je treba §e pripomniti, da je Gavazzi geografsko stolico kot redni profesor prevzel na pragu svojega \estdesetega leta. Že drugo leto po prihodu v Ljubljano pa je bil tudi njen dekan. Poleg tradicionalnih fizixnogeografskih vej (klimatologije, hidrologije, geomorfologije) je Gavazzi predaval Itudi splosno fizi¿no geografijo pa tudi astronomsko. Matematiðna geografija ima na filozofski fakulteti potemtakem že staro tradicijo, Ceprav je bila kasneje skoraj dvajset let pretrgana, podobno kakor pri hidrogeografiji in splosni fiziðni geografiji. Ni pa mogel Gavazzi, ki je na ljubljansko univerzo prišel z zagrebške oziroma beograjske univerze, svojega pedagoß̌kega dela povezati z znanstvenim neposredno na slovenskem ozemlju, ker ga je pac premalo poznal. Tudi sicer je takratna geografija Łe v marsiðem tičla na starejsih, podedovanih izrocilih, ki so bila $\mathbf{v}$ zahodni Evropi medtem povečni že presežena.

Drugo razvojno obdobje je geografija na ljubljanski univerzi doživela s prof. A.Melikom. Ta cas, od 1928. leta do druge svetovne vojne in కe tik po njej, bi lahko oznacili kratkomalo za Melikovo obdobje, trikrat daljse od prvega. Pomeni pa s celotnega koncepcijskega vidika stroke bistveno razliko. Šele z Melikom se je namreč geografija na ljubljanski univerzi razvila ne le $\mathrm{v}$ duhu takrat moderne srednjeevropske geografske znanosti, temvec hkrati tudi kot nacionalna veda. Obenem se je tudi vsebinsko izpopolnila ter tematsko zaokrožila. $V$ tem času sc niso nadaljevala le predavanja fiziðne geografije, temveð so obenem stekla tudi intenzivna fiziðnogeografska raziskovanja Slovenije, s poudarkom na geomorfoloskih in klimatoloških raziskavah, medtem ko je hidrologija stopila $\mathbf{v}$ ozadje. Tudi laboratorijsko in instrumentalno terensko delo je bilo pretrgano. Pax pa je prof. Melik takorekoč na novo razvil družbenogeografska in regionalnogeografska predavanja ter raziskovanje. Eno in drugo je bilo v tem casu že toliko zaokroženo, da moremo upraviðeno govoriti o kompletirani znanstveni geografiji v evropskem pomenu, ceprav je słonela le na enem profesoru in enem asistentu (J.Rakovec 1927-1933, Ilesix 1953-1985). Tolikšen obseg predavanj je bil mogoč le s sistemom Stiriletnega ciklusa, kajti Łele nekaj lct pred vojno je pedagołko delo v letih 1936-1943 najprej okrepil privatni docent za regionalno geografijo (dr.V.Bohinec) in kasneje, že na pragu vojne (1940. leta), se drugi (dr.S.Ilešic).

\footnotetext{
*Gavazzi je bil doma iz Splita, zato njegova maritimna raziskovalna usmerjenost ni naključna in tudi ne to, da je tudi $v$ L jubljani prvo instrumentalno opremo namenil raziskavam mor ja in jezer. Iz tega casa izvira tudi prevesni vodni termometer, $s$ katerim je 25 let kasneje, že po drugi svetovni vojni, R. Gradnik meril globinske temperature Blejskega in Bohinjskega jezera. Gavazzijev prevesni termometer smo uporabljali క̌e v začetku sedemdesetih let, torej క̌ petdeset let po nabavi.
} 
Celotno delo je sicer potekalo $v$ prostorsko, personalno in gmotno zelo skromnih razmerah pa tudi studentov je bilo zelo malo, vsako leto na novo le po dva ali trije, $v$ vseh letnikih pa povecini ducat. V celoti se je uveljavil koncept moderne, enotne, posibilistißne geografije. Fizixna geografija je imela veliko težo ne le $\mathrm{v}$ studijskem programu, temvex tudi v raziskovalnem delu, z geomorfologijo kot elitno. Osnovne teze tega koncepta so se $v$ celoti podaljふ̌le ふe $v$ prva povojna leta.

Tretje razvojno obdobje - ce izpustimo okupacijska leta, ko je delo na univerzi poveCini zamrlo, vsebinsko pa pomeni nadaljevanje predvojnega - je že prvo povojno obdobje, ki ga moremo upraviŁeno oznaxiti kot Melik-Ilesicevo obdobje. Trajalo je tja do konca petdesetih let. Geografski institut je sicer ostal కe v istih, prostorsko in financno se vedno zelo utesnjenih okvirjih, vendar že s prvimi kadrovskimi okrepitvami. Takoj po vojni se je geografski institut naposled le okrepil s prof. Ilesixem kot drugim rednim uxiteljem ter nekaj let kasneje (1951) tudi z drugim asistentom (V. Klemencic), medtem ko so se na mestu prvega asistenta $v$ prvih petih letih po vojni (1946-51) zamenjali kar trije (C.Malovrh, S. Zrimec, V.Kokole). V skladu s tedaj enotno pojmovano geografijo sta bili poleg obeh profesorskih mest tudi obe asistentski opredeljeni le kot geografski, dejansko pa sta se po 1951. letu oba asistenta (V.Kokole, V.Klemen $x_{i \chi}$ ) usmerjala $v$ družbeno geografijo, Ceprav je prvi కe uresniceval koncept enotne geografije, saj je zað̌el z geomorfološkimi prouðevanji, medtem ko je doktorat žc usmeril v regionalnogeografsko, drugi asistent pa se je že skraja oprijel le družbenc geografije. Tu so tudi zacetki kasnejß̌ega nesorazmerja med fiziÆno in družbeno geografijo. Še posebej, ker je po politični diferenciaciji na takratni univerzi cstal na geografskem inštitutu le drugi asistent.

Za naš pregled je pomembno, da sta se prejšnjima fiziěnogeografskima predmetoma (geomorfologiji, klimatologiji) pridružila కe predavanja hidrogeografije, pedogeografije in fitogeografije (pa tudi matematixno geografijo $\mathrm{z}$ osnovami kartografije moremo Steti v ta okvir), ki jih je prevzel prof. Ilesic. S tem je bila v prvih povojnih letih fizična geografija domala v celoti zaokrožena.

Bistveno novo razvojno obdobje, cetrto po vrsti, zelo dinamixno, polno sirokega razmaha pa tudi క̌tevilnih protislovij, se je zacelo na pragu Sestdesetih let. Oznaciti ga moremo kot Ilesixevo obdobje, ceprav je bil prof. Melik do 1966. leta Se aktiven, in Ceprav so se $\mathbf{v}$ pedagoški in raziskovalni proces zaðelo vkljucevati mlajši geografi, tokrat že iz povojne generacije. V komaj štirih letih, od 1958. do 1962. leta, se je namrex geografski oddelek okrepil s sestimi novimi ucitelji, od katerih so bili prvi Štirje pred tem asistenti (V.Klemenčic, I.Vrišer, M.Žagar, D.Radinja, J.Medved, V.Leban) in štirimi asistenti (Jur.Kunaver, M.Natek, Jelka Kunaver kot strok. sod., M.Pak). Med uxitelji je bilo pet družbenih geografov in le eden fizieni (D.Radinja) in tudi med asistenti je bil le eden fizicni (Jur.Kunaver). Skoraj trikratni porast oscbja je odražal nedvomno najbolj radikalno reformo, ki jo je geografija, podobno kot celotna univerza, dosle j doživela. 
Prišlo je do številnih, že na zunaj vidnih sprememb in \e pomembnejših notranjih. Vsch tu niti ni mogoce našteti. Med zunanjimi velja najprej omeniti, da se je geografija takrat preselila v sedanje prostore na Askerとevi ulici, v novo stavbo filozofske fakultete, ki je ta dotedaj sploh ni imela. Prostori so bili nekajkrat obsežnejši od prejšnjih. Prvikrat so poleg ưiteljev in sodelavcev dobile svoj prostor knjižnica, kartografska zbirka, risalnica pa seveda študenti (dve predavalnici, Studijsko sobo). Kmalu zatem sta dobila prostore కe nanovo osnovana fizixnogeografski laboratorij s praktikumom in fotolaboratorij. Poleg bibliotekarke (T.Šifrer) in kartografa (M.Žerovnik) pa so se izpopolnili కe štirje tehnienni sodelavci, med njimi dva laboranta. Razmah stroke je potemtakem omogocila sele povojna doba. Celo v toliksni meri, da je kvantitativni razvoj sprva presegel kvalitativnega.

Še pomembnejక̌e so bile vscbinske spremembe. Celotni క̌tudij se je bistveno predrugačil. Do kraja je bil speljan ne le sprotni, letniški sistem, ki je postopno zamenjal ciklix̌nega, temveč tudi stopenjski in inverzni. To je seveda terjalo povcčano število predavateljev in asistentov. Poleg pedagoß̌kega dvopredmetnega študija je bil vpeljan కe nepedagoški (enopredmetni in dvopredmetni) $\mathrm{z}$ vrsto pomožnih predmetov. Študij se je razdrobil, povecalo se je stevilo delnih izpitov, kolokvijev, pismenih vaj, seminarskih nalog, vpeljano je bilo diplomsko delo in spremenila se je tudi fiziognomija diplome. Celotni studij je dobil nekatere prvine srednje sole. Spremenili so se tudi nazivi diplomiranih geografov. Povecala se je sistematiðnost ekskurzij, ki so se kasneje dopolnjevale $s$ stacionarnim terenskim delom. Poleg treh temeljnih kateder ( $z a$ fiziŁno, družbeno in regionalno geografijo) so bile kasneje vpeljane še stiri druge (1978), ki so pomenile razvejanost Študijskega in raziskovalnega dela. Za vodstvo oddclika se je vpcljalo načclo rotacije. Sploh se je moral oddelek (takrat se je tudi preimenoval) preoblikovati $\mathrm{v}$ dobro organizirano cnoto. Za ǔitelje in kasneje tudi asistente so bili prvič vpeljani nazivi za osnovne usmeritve (ư̌itelj za fizǐ̌no, družbeno ali regionaino geografijo), čeprav ne dosledno. Za ene in druge pa so bile na celotni univerzi vpeljane reelekcije s trojnimi merili - strokovnimi, pedagoskimi in družbenopolitixnimi. Do vseh tch sprememb ni prišlo na samem zax̌tku šestdesetih let, temveč tudi še s kasnejక̌mi reformami. S stopenjskim in razvejanim študijem sc je mođno poveðalo število studentov, saj se je samo v prvi letnik vec let zapovrstjo vpisovalo trikrat veट Studentov, tudi do 120 . Zato se razmerje med njimi in uxitelji kljub omenjenim okrepitvam slednjih ni bistveno izboljšlo, v marsixem se je celo posiabšalo. Število studentov se je kasneje le polagoma zmanjševalo, predno se je razpolovilo, sedanji vpis pa je tako in tako omejen.

$\mathrm{V}$ scdemdesetih letih se je pedagosko delo se nadalje drobilo. Koncept enotne geografije se je dokonæ̌no osul, zamenjal ga je dualistið̌ni, ce že ne dezintegracijski, ki pa se teoretsko ni utemeljeval, postajal pa je tudi cedalje bolj pritisloven. Odtod nasprothe težnje, zlasti prof. Ilešł̌a, vendar je కel razvoj večinoma svojo, pragmatiðno pot. 
Ta razvoj pa bi bil brez prof. Ilešica nedvomno manj skladen in manj konsistenten. Posledice so se kazale na pedagoß̌kem in raziskovalnem podroðju. Pojasnjevalo pa se jih je povexini $z$ naglim razvojem stroke ter vrenjem $v$ njej, kar naj bi bilo znaxilno za geografijo nasploh, ne le v Jugoslaviji, temvec tudi sicer po svetu.

Za fizǐno geografijo ni brez pomena, da so $\mathrm{v}$ Sestdesetih letih presahnile studijske povezave $z$ naravoslovnimi predmeti (biologijo, geologijo, meteorologijo), ki žc prej niso bile pogostne. Kot nekakకno nadomestilo sta zadnja dva predmeta v okviru geografskega programa postala pomožna. Študijske povczave so se sicer omejevale na družboslovne stroke. Hkrati je znaxilno, da je tradicionalno povezavo z zgodovino, ki je nekdaj prednjacila, zamenjala sociologija, saj se je tudi sama geografija precej sociolosko usmerjala. Nasploh pa se je stevilo študijskih povezav mořno povezalo, kajti zaje!c so ve飞ino strok, ki so na fakulteti zastopane, vkljuðno z jeziki.

Na zađetku sestdesetih let porušeno ravnotežje med fizǐnimi in družbenimi geografi se je nekoliko omililo seie 1967. leta s prihodom prof.I.Gamsa, ki je prevzel predavanja geomorfologije, klimatogeografije in biogeografije. Dobrih deset let kasneje (1978) se je kot uxitelj pridružil Se dr. F.Lovrencak, pred tem od 1966. leta asistent, ki je med drugim prevzcl tudi predavanja fitogeografije in pedogeografije. $V$ zadnjem casu se je fiziðna geografija okrepila కe $\mathrm{z}$ dvema uxiteljema - prof. J. Kunaverjem (1986) in doc.D.Plutom (1986), ki je bil pred tem od 1974. leta asistent. Poleg petih uxiteljev sta med fizičnimi geografi še dva asistenta - mag. M.Bat od 1982. Icta in D.Ogrin (1987) kot stažist raziskovalec. Tako se je razmerje med fizicnimi in družbenimi geografi v glavnem uravnovesilo కele $\mathrm{v}$ zadnjem casu.

Značilna je orientacija podiplomskega izpopoinjevanja sedanjih uð̌iteljev fizične geografije v inozcmstvu, ki ni potekaia le v okviru ene od cvropskih gecgrafskih sol, temveč na razliðnih, namreð na univerzah v Angliji, Franciji, Nem̌iji, Češkosłovaški in v Sov jetski zvezi. Tudi po doktoratih sestava uxiteljev ni enostranska. Poleg doktorata iz regionalne geografije sta dva geomorfološka ter po eden fitogeografski in hic̈rogeografski. Značilen pa je deiež fiziðnogeografskih doktoratov, ki so opravljeni po vojai. $V$ tem casu je bilo takih doktoratov 16 , kar je približno cetrtina vseh geografskih. Pri ten je znaxilno, da so le $v$ prvem obdobju prevladovali geomorfološki. Podoten kakor pri doktoratih je tudi delež fiziŁnogeografskih magisterijev, namreð sedem od skupno sedemindvajsetih.

V zadnjih dvajsetih letih so se predavanja fizične geografije razširila in poglobila. $V$ marsi $x_{c m}$ so se spremenila koncepcijsko, zajela pa so tudi nekatera nova podroxja (Gams 1972, Meze 1972, Šifrer 1972). Poleg geomorfologije velja posebej omeniti కe geografijo krasa, ki ni zasnovana samo morfogenctsko, temveð̌ precej క̌rše. Na novo se je razvila tudi geografija mor ja (maritimna geografija), ki prav tako ni zasnovana 
le fizixnogeografsko. Nasploh pa velja, da se studijsko (predavateljsko) delo na podrox ju fiziðne geografije cedalje bolj povezuje $\mathrm{z}$ raziskovalnim, $\mathrm{s}$ terenskimi vajami in tudi $\mathrm{z}$ nekaterimi skupinskimi raziskavami, organiziranimi $\mathbf{v}$ okviru katedre za fizieno geografijo. V njej se ni strnilo le celotno pedagosko delo, temveđ tudi veð̌ina raziskovalnega. Posebej je treba omeniti, da se je pred dobrimi desetimi leti habilitiral za uxitelja tudi biogeograf (F.Lovrencak), kajti ta veja je bila med fiziðnogeografskimi vejami najbolj zanemarjena. S tem so se vse fizixnogeografske veje kompletirale ne le Studijsko, temveð tudi raziskovalno. Če smo natanØni je treba priznati, da se med fizi仑̌nogeografskimi vejami doslej se ni razvila edinole zoogeografija. Toda to je znacilnost večine geografskih కol po svetu. Šele $\mathbf{v}$ zadnjem casu njena vloga na pomenu nekoliko pridobiva zaradi ekološkega vidiika.

V zadnjih treh desetletjih se tudi $v$ fizixni geografiji cedalje bolj uveljavljajo kvantitativne metode. Zato ni nakljucje, da je v Sestdesetih letih prišlo do ustanovitve fiziそnogeografskega laboratorija s praktikumom, do uvajanja laboratorijskih vaj in pri tcrenskih vajah do uporabc instrumentalnih metod, pa seveda tudi racunalniških.

Prevcliko razdrobljenost geografskega Studija blažijo predavanja, ki so v osnovi sicer fizǐnogeografska, vendar so sirక̌e zastavljena. Poleg geografije krasa in maritimne geografije, velja to zlasti za predmeta, vpeljana ob zadnji studijski reformi (1978). Prvi je pokrajinska ekologija in drugi varstvo geografskega ckolja. Fizißni geografi so poleg matematixne geografije prevzeli tudi del regionalnogeografskin predavanj ter didaktiko geografskega pouka. $\mathrm{S}$ tem se $\mathrm{v}$ marsixem blaži dualistix̌na usmerjenost geografije.

Delež fiziðne geografije se je $\mathrm{v}$ zadnjem Casu precej uravnotežil $\mathrm{z}$ družbenogeografskim in regionalnogeografskim. $\mathrm{V}$ koncepcijskem in vsebinskem pogledu sploh za to razvojno obdobje lahko rečemo, da poteka v znamenju prof.Gamsa. Tako ni le zaradi njegovega predavateljskega deleža, temveč tudi zaradi izredno plodnega raziskovalnega ter $s$ tem povezanega publicistiðnega. $V$ okviru katedre za fizično geografijo, ki jo je ves ta Cas vodil prof. Gams, je bilo izpeljanih veð skupnih projektov, naj je šlo za simpozije (slovenske, jugoslovanske, mednarodne), za skupinske raziskave, npr. za kvantitativno prirodnogeografsko regionalizacijo Slovenije, za slovensko krasko terminologijo, za geomorfološko karto, za skupna raziskovanja s studenti itd. Še posebej je treba omeniti idejno, teorctsko in metodološko usmerjanje, ki ga na razli¿ne načine ne le v fizienni geografiji, temveð tudi šrše opravlja prof.Gams. Toda ko govorimo o soli, ki se je razvila v okviru fiziłne geografije, je treba vendarie na prvo mesto postaviti krasoslovno $\mathrm{z}$ mednarodnim ugledom. Zato ni naklju $\chi_{j e}$, da prihajajo na podiplomsko izpopolnjevanje tudi geografi iz inozemstva. 
Čeprav gre za proslavo, je bilo v pravkar izreð̌nih besedah več kritið̌nih misli, ker menim, da so takSne besede, hkrati z iskanjem boljsih poti za nadaljnji razvoj, koristnejse od poudarjanja uspehov slednjega, pa tudi sploß̌ne razmere ne spodbujajo. Kaže, da je ekstenzivna pot razvoja dokoňno za nami in da se bodoci razvoj prevesa $\mathbf{v}$ intenzivnejsega, ki bo veliko bolj kot doslej terjal osnovno specializacijo naše stroke, namrex specializacijo povezovanja posameznih delov geografije $\mathrm{v}$ celoto, seveda $\mathrm{z}$ ustreznim teoretskim, metodoloskim in stvarnim utemeljevanjem.

V okviru fizixne geografije pa sedanje specializacije terjajo tudi formiranje (obnavljanje) splošne fiziðne geografije ter $\mathrm{z}$ njo povezan కtudij fizi仑nogeografske regionalizacije. Podobno kakor se gcomorfologija in klimatogeografija v studijskem programu opirata na gcologijo inmeteorologijo, se bodo morale na pomožne predmete naslanjati tudi druge fiziŁnogeografske veje, కe posebno v okviru enopredmetne studijske skupine, ki jo kaže dokon`no uveljaviti, pravzaprav obnoviti. V vecji meri kot dosiej naj bi fiziðni geografi poleg fizixnogeografske misli poglabljali tudi splošno geografsko ter tako pripomogli, da bi ožje raziskave v veð̌ji meri temeljile ne le na posebnih, temveð tudi skupnih teoretskih in drugih osnovah geografske znanosti kot celote. 


\section{LITERATURA IN VIRI}

Gavazzi A., 1922, Geografski institut sveucilista u Ljubljani, Nastavni vjestnik 32, Zagreb.

Gams I., 1972, Geografsko raziskovanje krasa v Sloveniji, Geografski vestnik 44, Ljubljana.

Gams I., 1983, Stanje in perspektive slovenske raziskovalne geografije, Geografski vestnik 60 , Ljubljana.

Gams I., 1986, O položaju geografije v Raziskovalni skupnosti Slovenije, Geografski vestnik 58, Ljubljana.

Ilesix S., 1940, Ob petdesetletnici Antona Melika, Lj.zvon, Ljubljana.

Ileši S., 1950, Slovenska geografija v 30 letih ljubljanske univerze, Geografski vestnik 22, L jubl jana.

Ileši S., 1960, Ob sedemdesetletnici prof. Antona Melika, Geografski vestnik 32, Ljubljana.

Ileši S., 1969, Geografija. Petdeset let slovenske univerze v Ljubljani, Ljubljana.

Ilesic S., 1979, Pogledi na geografijo, Ljubljana.

Kokole V., 1966, Anton Melik - in memoriam, Geografski vestnik 38, Ljubljana.

Meze D., 1972, Klimatska prouð̌evanja Slovenije, Geografski vestıik 44, Ljubljana.

Pak M., 1981, Nekaj misli o položaju v slovenski geografiji, Geogrf.vestnik 53, Ljubljana.

Rakovec I., 1945, Dr.Artur Gavazzi (14.10.1861 - 12.3.1944), Geografski vestrik 17, Ljubljana.

Šifrer M., 1972, Nckatere smeri in pogledi geomorfoloßkega proucevanja na Slovenskem, Geografski vestnik 44 , Ljubljana.

VriKer I., 1986, Geografija - humanistǐna veda, Geografski vestnik 58, Ljubljana.

Razprava o geografiji (I.Gams, P.Habix, V.Kokole, V.Klemencic, J.Kunaver, A.Lah, D.Radinja, I.Vrišer), Geografski vestnik 53, Ljubljana 1981.

Arhiv oddelka za geografijo filozofske fakultete, L jubljana.

Petdeset let slovenske univerze v L jubl jani, 1919-1969, L jubl jana.

Zbornik filozofske fakultete v Ljubljani, 1919-1989, Ljubljana. 


\section{SIEBZIG JAHRE DER PHYSISCHEN GEOGRAPHIE AN DER UNIVERSITÄT VON LJUBLJANA}

Auf der Universităt von Ljubljana begann die Geographieforschung und das Geographiestudium durch dic physische Geographie (1921), denn der erste Professor der aus Zagreb kam ist der Geograph A. Gavazzi gewesen. Die Anthropo - und Regionalgeographie wurden erst nach dem Jahre 1927 mit Professor Melik ein aktives Bestandteil der hiessigen Geographie.

Die Geographicentwicklung und darunter auch der physischen, konnte auf mehrere Zeitabschnitte aufgegliedert werden. Der erste typische physischgeographische Zeitabschnitt dauerte sieben Jahre (1921-1927). Nach dem damaligen Professor können wir diesen als Gavazzi Zeitabschnitt bezeichnen. Die Geographic hatte damals noch den Schleier alter Zeiten getragen, wichtig war jedoch ihr Bestehen aus wissenschafts-oragnisatorischen Gründen. Es wurde das Geographische Institut gegründet (1921), es entstanden die Bibliothek und die kartographische Sammlung. Gegründet wurde aber auch das ozeanologische und lymnologische Laboratorium.

Der folgende Zeitabscinnitt ist dreimal lănger gewesen(1927 - 1946). Die Geographie ist zu einer modernen mitteleuropasischen und nationalen Fachwissenschaft geworden. Sie begann năhmlich das Heimatland Sloweniens systematisch zu untersuchen. Professor Melik, der diese Forschungen leitete, ist zum crsten s!owenischen Universitätsprofessor der Geographic ernannt worden. Innerhalb der physischgeographischen Forschungen und Vorlesungen widmete man der Geomorphologie und Klimatologie die meiste Zeit. Beide stützlen sich an Fachuntersuchungen innerhalb Sloweniens. Nach dem damaligen Professor konnte man diesen Zeitabschnitt den Professor Mclik widmen.

Der folgende Zeitabschnitt dauerte ungefăhr 14 Jahre (1946-1959) und könnte nach den beiden damals tătigen Professoren Melik-Ileši bennant werden. Zu dieser Zeit kam an die Universität von Ljubljana noch ein zweiter Professor - năhmlich Ile ̌ið. Die Vorlesungsausrichtung und die Fachforschungen verbreitcten sich auf fast alle physischgeographische Zweige. Nebst geomorphologischen und klimatologischen wurden auch hydrogeographische, pedogeographische und phytogeographische Studien gefertigt und Vorlesungen geführt. In der slowenischen Geographie konnten nebst mitteleuropäischen auch Einflüsse Westeuropas, besonders der französischen possibilistischen Schule erkannt werden. In den sechziger Jahren kann man von dem Ilesix Zeitalter sprechen. Es waren Zeiten der radikalen Universitătsreformen die auch das Studium der Geographie sehr beeinflussi haben. Die Geographichat neue Răume und neue Professoren und Assistenten gewonnen, gieichzeitig wurde aber auch die bestehende 
Abteilung durch drei Lehrstühle gegründet. Die zyklischen Vorlesungen wurden mit jăhrlichen ausgetauscht. Das Studium wurde auf zwei Studienebenen - der höheren und der Hochschule - geführt. Nebst der zweifächigen pedagogischen wurde auch die "nichtpedagogische" Fachausrichtung des Geographiestudiums eingeführt. Das Forschungsprogramm wurde immer breiter und spezialisierter, weswegen nicht nur ein Dualismus sondern auch Desintegrationstendenzen, ăhnlich weltweiten Entwicklungen, im Fach zu spüren waren.

Anfangs der siebziger Jahre begann im Rahmen der physischen Geographie ein Zeitabschnitt den wir nach dem führenden physischen Geographen Professor Gams, auch als den Gams Zeitabschnitt ansehen. Physischgeographische Vorlesungen wurden vertieft und die ersten Reintegrationstendenzen wurden geăussert. Nebst erwähnten klassischen Vorlesungen sind noch die Geographie des Karstes, die Landschaftsőkologie, die maritime Geographie und der Umweltschutz eingeführt worden. Die Karstologie war traditionsfolgend führend. Die pedagogische und wissenschaftliche Tătigkeit kontzentrierte sich im Rahmen des physischgeographischen Lehrstuhles. Dieser hat derzeit fünf Professoren und zwei Assistenten.

Für die Entwicklung der physischen Geographie ist es nicht unwichtig, dass die Geographie in den ersten dreissig Jahren (1920 - 1950) auf der Phylosophischen Fakultät ihren Sitz hatte.In dieser Zeit wurden darin humanistische und naturwissenschaftliche Fåcher vereint. In den năchsten zehn Jahren fand man die Geographie an der Naturwissenschaftlich - mathematischen Fakultăt (1950-1959), die letzten dreissig Jahre ist die Geographie erneut ein Bestandteil der Phylosophischen Fakultăt die aber nun nur humanistische Föcher vereint. Eine der Folgen dieser Aufteilung ist, dass die Geographie im Rahmen des Studiums nicht an naturwissenschaftliche Fachausrichtungen, sondern mit humanistischen, bzw. gesellschaftlichen gebunden ist. 